\title{
AN EMPIRICAL ANALYSIS OF COMPETITIVENESS FACTORS OF THE REGION'S AGRARIAN SECTOR
}

\author{
Nadiia Pylypenko ${ }^{1}$, Nataliia Klietsova ${ }^{2}$, Iryna Stoianenko
}

\begin{abstract}
Purpose. The analysis of theoretical concepts of sustainable competitive advantage, the assessment of the competitive advantages of the agricultural sector in the region and identification of the opportunities to provide competitive advantages under conditions of instability as well as a changeable business environment. Results. Two opposite concepts of sustainable competitive advantages' sources are analyzed. The first one is resource-oriented, the second one - based on the influence of the external environment on the competitive position of the company. It is found out that in modern conditions, the concept based on the resource approach is more adequate for the agrarian sector as the business features in agriculture predetermine the considerable resources' immobility. In agriculture, due to the specificity of rural settlements, the combination of the basic resources (land, machinery, people) causes a quite rigid configuration that cannot be changed quickly enough. But the resources themselves are not a source of competitive advantage; the ability to use available resources effectively is important. The authors propose a method for comparing the security and efficiency of the basic resources' usage in agriculture by region. Under the framework of the methods, it was put the index method that allows comparing individual indicators and defining the integral index. The authors used such indicators as energy capacity, tractors and labour resources per one hectare of agricultural land to estimate resource availability. Resource efficiency is characterized by labour productivity indicators (gross production per one average annual employee) and land productivity (gross production per one hectare of agricultural land). The integral indices were calculated based on the geometric mean. There was done the comparative analysis of the provisions of basic resources and the efficiency of their usage by agricultural enterprises of Sumy region, neighbouring regions as well as the average industry indicators based on the proposed methodology. The analysis confirmed the existence of sustainable competitive advantages in the regional context and found that the leading resource is not natural characteristics, but effective management, which provides the highest efficiency of management. Conclusions. Taking into account the rapid changes in the business environment, any competitive advantage can quickly turn from sustainable to unstable. An assessment of the competitive advantages of the agrarian sector in the region has shown that to provide a sustainable position, it is first and foremost necessary to focus on reducing the costs and use innovations. Under conditions of rapid technological change, the main resource is human ones that can produce certain knowledge and innovative solutions. The proposed method of calculation of the integral indicators of resource availability and efficiency of their usage allows evaluating the existence of competitive advantages objectively and can be used both for the development of competitive strategies of agricultural enterprises and the preparation and decision-making at the level of central and regional authorities.
\end{abstract}

Key words: competitive advantage, resource efficiency, agrarian sector, competitive advantage assessment, competitive strategies.

JEL Classification: Q13, R13, D24

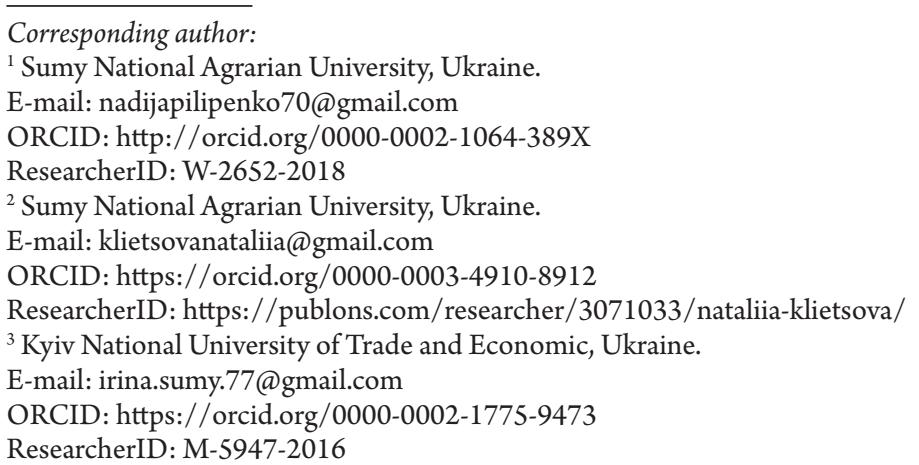




\section{Introduction}

Instability of economic development, both of global economic space and national economies, increased competition, rapid technological changes require constant response to provide the competitiveness of companies. Recent changes in the agricultural sector in Ukraine indicate that there are negative trends in the number of enterprises, the number of employees involved in agriculture and a significant reduction in the production of livestock products. The above is caused by a number of factors: the significant monopolization of the agrarian sector has led the large producers to concentrate on growing only certain highly profitable crops whose production process is almost completely mechanized. More than ever, there is the problem of food security and the provision of livestock products to the population. Small-scale farmers, who can solve these problems, are unable to compete with large agricultural holdings that have large areas of agricultural land in their use and are more efficient and competitive due to the significant cost and production benefits of exportoriented crops. Research on the competitive position of small agricultural enterprises has identified weaknesses in their activities (Pylypenko, 2016).

Therefore, there are two types of producers in the agrarian sector of Ukraine: large agricultural enterprises that, through economies of scale, ensure high production efficiency, have access to foreign markets and occupy a dominant position in the industry; and small agricultural enterprises that have small areas of agricultural land and do not occupy a dominant position in the market but, at the same time, perform an important social village conservation function (Hadzalo, 2015). Ensuring further development of such small village conservation enterprises is possible on the basis of achievement of sustainable competitive advantages. In this regard, there is a need to find new ways and methods of providing the competitive advantages of small farmers.

The development of areas of competition and the search for new sources of competitive advantage based on their assessment is quite relevant in the current environment. A significant contribution to the research of competitiveness issues, evaluation and search of areas of functioning of competitive advantages has been made by Barney J., Wang H., Hart S., Yudanov A., Mugera A., Grant R., Hamel G., Wernerfelt B., Porter M. and others. But their concepts of providing competitive advantages are not sufficiently adapted to the conditions of doing business by agricultural producers in the Ukrainian realities. The urgency of this problem determined the purpose and objectives of the research.

The purpose of the study is to analyze theoretical concepts on the formation of sustainable competitive advantages, assess the competitive advantages of the agricultural sector of the region and identify opportunities to provide competitive advantages in the conditions of instability and changes in the business environment.

\section{Theoretical aspects of competitive advantages' formation}

Attention to competitive advantage is increasing, and new features are emerging with particular emphasis on competitiveness such as sustainability (Barney, 1991; Vinayan, Gowrie, Jayashree, Sreenivasan \& Marthandan, Govindan, 2012). The development of a competitive strategy, as a decisive factor in the successful development of any entity, is a sustainable competitive advantage. The rapid technological development that is happening around the world leads to the search for new factors of influence on competitive advantages, as all the new factors of their provision such as innovative development and organizational culture of companies came to the fore (Vinayan, Gowrie, Jayashree, Sreenivasan \& Marthandan, Govindan, 2012).

There are two opposite concepts of the sources of sustainable competitive advantage in the scientific literature: the Resource-Based Approach of sustainable competitive advantage (Barney, 2011) and models based on the research of the environmental impact of a firm's competitive position (Porter, 1985). From the standpoint of the proponents of the resource approach (Barney, 1991), a source of sustainable competitive advantage is resources that are endowed with a set of attributes, such as rarity, infirmity and uniqueness. The presence of these special features is reflected in the immaturity of resources, which protects the firm from copying and imitation of its economic behavior by competitors. Peteraf (1993) considers the main criterion for sustainable competitive advantage is immobility and long-term constraint. The more resource is available in the market, the less unstable the competitive advantages will be.

The sustainability of competitive advantages depends not on the calendar period but on whether the competitive advantage remains after the efforts of competitors to follow it. If the firm's resources are homogeneous and mobile, sustainable competitive advantage cannot be secured. Therefore, according to proponents of resource theory, the search for sources of sustainable competitive advantage should focus on the heterogeneity and infallibility of resources.

According to Porter's point (Porter, 1985), the firm's competitive position depends on the particular industry to which it belongs. He assumed that resources in one industry were identical and that their heterogeneity was a temporary phenomenon. Porter's "five forces" model explains the influence of external factors on the competitive environment of firms in the industry. The total impact of these forces depends on the type of industry. In those industries where one of the forces 
is active enough, only a small number of firms can count on high profits. Porter has two competitive advantages: low cost and product differentiation. But there are contradictions when using these two types, as differentiation implies cost increases, which can lead to a loss of competitive advantage in the form of lower prices for a particular segment of the market, but those firms that are able to combine the two types successfully will be rewarded in the form of sustainable competitive positions. It is clear that such a combination should not be copied by competitors. According to Porter, the basic components of competitive advantage are specialized activities. An activity-based approach allows you to analyze the firm's competitive advantage. A potential source of competitive advantage is a successful combination of different activities. Competitive advantages are the result of the implementation of a set of individual activities of the firm. The small number of activities creates the conditions for copying and imitation of the behavior of the firm by other competitors. It is through activities that determine the resources that a firm must acquire. That is, the selection of resources by the firm is made after the analysis of the competitive environment and the choice of strategy. In order to ensure sustainable competitive advantage, a firm must create barriers that make it difficult to imitate its actions by competitors. The existence of barriers, even with the uniformity of resources, according to Porter, provides an opportunity for the firm to gain competitive advantage, but Barney notes that barriers are only possible in the case of differences in resources, between firms in the industry and firms that trying to enter the industry. That is, barriers are a source of competitive advantage, only in the case of heterogeneous distribution of resources.

Therefore, Porter's theory of competitive advantage is focused on external factors of competitive advantage. The reason for the heterogeneity of firms was the structure of the industry in which they work. However, within one industry, firms are significantly different, especially in agriculture. The instability and uncertainty of the sectorial structure due to the transformation processes caused by globalization and rapid technological development have led to a weakening of the dominance of this concept.

Critics of this concept, the founders of the resource approach (Barney, 2011; Wernerfelt, 1984; Prahalad \& Hamel, 1990; Grant, 1991), consider that it does not pay enough attention to influence on competitive advantages of the firm's internal signs. Wang (2014) notes that Porter's "five forces" model has limitations as it implies the existence of a perfectly competitive market that is virtually non-existent in our current environment. Wernerfeld, unlike Porter, views the firm's activities in terms of resources rather than products. $\mathrm{He}$ views the firm as an aggregate of assets and resources. Availability and substitutability of the resource will reduce the profitability of its owners. If the production of the resource itself and its component is monopolized, it will reduce the income of other producers who do not have such a resource. It's nothing like a resource barrier that is similar to traditional entry barriers. It is important to strike a balance between the exploitation of existing resources and the development of new ones (Wernerfelt, 1984).

According to Hamel and Prahalad, who have extended the resource theory, the production of a unique product is driven by new knowledge that arises from the effective combination of available resources, knowledge and processes. That is, the ability to produce new knowledge and use it to grow a company and adapt to the environment faster and better than its competitors is the only source of sustainable competitive advantage. Knowledge, skills, organizational culture cannot be copied by other competitors. Thus, a firm's economic growth provides the company's management with the ability to transform existing resources into competencies. The competencies will ensure the adaptation of the company to the changing market conditions and the compliance of internal and external conditions. High adaptability is closely linked to the continuous process of acquiring and producing new knowledge (Prahalad \& Hamel, 1990). A similar view is expressed by Urlich and Lake (1991), who believe that it is more important to focus on managing core competencies in business planning than in the market or the product.

Grant (1991) considers the capabilities of the firm, the source of which to be a major source of competitive advantage. Companies whose strategies were based on internal resources had a better adaptation to changes in the external environment. But in his view, resources themselves are not a source of concrete benefits. Resource characteristics such as poor mobility, difficulty of reproduction, durability and transparency are the reasons for the success of the enterprise in the long run. The faster the resources are depreciated, the less their longevity. The higher the transparency, it is less likely for competitors to identify which resources underlie this competitive advantage. Imperfect mobility is manifested in the fact that moving resources from one company to another will not produce the same result. Providing resources with the necessary characteristics and capabilities to use them effectively is ensured by a special, non-imitable kind of resource - the competencies or abilities whose involvement in the organization makes them inseparable from it (Grant, 1996). Therefore, learning from the experience and trying to copy it from other companies should not produce results. Access to machinery and equipment is not a differentiating factor, but the ability to use existing resources effectively is important (Mugera, 2012).

Barney (1991) also denies the existence of sustainable competitive advantages of the innovator, as the uniformity of resources will not be an obstacle in the future for imitation of competitors in their activities. 
Barriers to entry into the industry also do not provide sustainable competitive advantage. But, at the same time, the existence of barriers is the result of firms implementing strategies that cannot be applied by firms that want to enter the industry. Therefore, barriers exist only when firms are different in their resources. That is, the source of competitive advantage is the unique combination of resources available to the firm. It is the uniqueness of the combination, which is provided through the most important resource - knowledge, makes it impossible for them to be imitated by other companies. Thus, resource potential is a source of distinction for firms, as evidenced by the fact that under the same conditions of operation provide different results within the same branch of the enterprise.

But physical capital and technology can be a source of competitive advantage only if the firm has unique social capital.

Achieving sustainable competitive advantage is possible through the following aspects (effective supply chain management, product and innovation differentiation, organizational responsiveness; cost of leadership that delivers lower prices). Sustained competitive advantage creates unique resources combined with a suite of appropriate management actions and decisions. Resources should be rare, irreplaceable, heterogeneous, immutable, and nontransferable (Vinayan, Gowrie, Jayashree, Sreenivasan \& Marthandan, Govindan, 2012).

Resources that do not increase a firm's revenue or reduce its costs are not a source of competitive advantage. Resources that are valuable and rare are a source of temporary competitive advantage. Resources that are valuable, rare and expensive to be imitated can be a source of sustainable competitive advantage. If competitive advantages can be copied by other firms, they are unsustainable (Barney, Ketchen \& Wright, 2011).

\section{Comparative analysis of the competitive advantages of the agricultural sector in the regional dimension}

Today, the agrarian sector is very labor-intensive and benefits from natural resources. But it has a negative impact on the environment and cannot be a source of sustainable competitive advantage. Physical resources can only give temporary benefits (Barney, Ketchen \& Wright, 2011). Hart (1995) examined the relationship between opportunities for pollution prevention, product management and sustainable development. He investigated the impact of the environment on the formation of competitive advantages. Environment is a component of resource theory. Constraints created by the environment will be an important factor in the firm's new resources. Only environmentally oriented resources will be a source of sustainable competitive advantage in the future. Thus, environmental friendliness can be an important competitive advantage. Establishing statespecific environmental requirements may be an external barrier to entry into the industry. Therefore, businesses will have a competitive advantage if they use new environmental technologies.

There are four main types of competitive strategies. The first strategy is the force acting in the field of largescale production of goods and services. This means that the company has relatively affordable prices and low costs. The second strategy is adaptable. If the firm is focused on small business, then it is likely that you will need to follow this strategy. The third strategy is a niche. This strategy involves deep specialization of production. The fourth strategy is innovative. It is not the firm that adapts to the market, but the market becomes completely different after the advent of this company (Yudanov, 2000).

According to M. Porter (1985), when choosing a competitive cost advantage, an enterprise should focus on manufacturing products that have competitors, but it should produce them at relatively lower costs than competitors. Choosing a competitive advantage strategy based on product differentiation, one should be ready for the ability to produce and deliver unique products to the buyer, with after-sales service, that is, constant contact with customers is required, which involves exploring consumer needs. The combination of these two strategies is complicated but quite profitable and possible due to innovation.

But in order to pursue an appropriate competitive strategy and acquire the necessary resources that will provide a lasting competitive advantage, the relationship between resources and competitive advantage must be understood.

To evaluate the competitive advantage, we have proposed an integral coefficient that takes into account the industry's potential and efficiency. The integral coefficient consists of several components, which gives the opportunity to identify problems in a particular area.

In agriculture, the main resources are land, machinery and people. The combination of these resources, due to the specificity of rural settlements, causes a certain, rather rigid configuration that cannot be changed, as a rule, quickly enough. This is especially true for small and medium-sized enterprises, which, unlike agricultural holdings, do not have sufficient investment resources for cardinal and rapid change. Regional features have remained so for decades. Comparative analysis of the level of provision of basic logistical, natural and human resources of agricultural enterprises of Sumy region and neighboring regions and within the industry, in general, is presented in Table 1 .

The analysis shows that the provision of basic resources has been deteriorating in recent years, with this trend is typical for the whole industry as well as for individual regions. 
Table 1

Level of basic resources' provision of agricultural enterprises

\begin{tabular}{|c|c|c|c|c|c|c|c|}
\hline \multicolumn{2}{|c|}{ Indicators } & 2013 & 2014 & 2015 & 2016 & 2017 & 2013-2017 \\
\hline \multirow{5}{*}{ 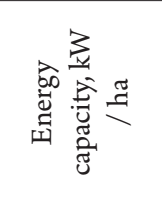 } & Ukraine & 2,02 & 1,91 & 1,51 & 1,66 & 1,59 & 1,74 \\
\hline & Sumy Region & 2,29 & 1,36 & 1,35 & 1,43 & 1,42 & 1,57 \\
\hline & Chernihiv Region & 1,51 & 1,39 & 1,33 & 1,25 & 1,27 & 1,35 \\
\hline & Poltava Region & 1,94 & 2,02 & 1,86 & 1,93 & 1,78 & 1,91 \\
\hline & Kharkiv Region & 1,82 & 1,89 & 1,65 & 1,76 & 1,68 & 1,76 \\
\hline \multirow{5}{*}{ 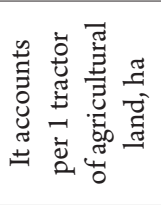 } & Ukraine & 160 & 169 & 168 & 161 & 166 & 165 \\
\hline & Sumy Region & 189 & 197 & 206 & 192 & 193 & 195 \\
\hline & Chernihiv Region & 186 & 204 & 217 & 232 & 235 & 215 \\
\hline & Poltava Region & 135 & 131 & 139 & 135 & 149 & 138 \\
\hline & Kharkiv Region & 147 & 141 & 162 & 155 & 159 & 153 \\
\hline \multirow{5}{*}{ 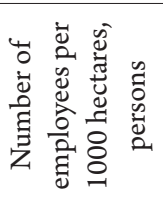 } & Ukraine & 31,0 & 29,9 & 29,7 & 26,6 & 25,9 & 28,6 \\
\hline & Sumy Region & 25,2 & 25,3 & 25,5 & 25,2 & 23,7 & 25,0 \\
\hline & Chernihiv Region & 30,5 & 30,3 & 28,6 & 23,0 & 23,6 & 27,0 \\
\hline & Poltava Region & 41,0 & 41,8 & 40,5 & 34,5 & 30,7 & 37,6 \\
\hline & Kharkiv Region & 29,1 & 30,3 & 26,0 & 22,1 & 22,4 & 25,8 \\
\hline
\end{tabular}

Source: the authors calculated on the basis of data (Derzhavna sluzhba statystyky, 2019)

If we compare with the EU countries - the neighbors of Ukraine, it should be noted that the availability of arable land tractors in Ukraine is almost 12 times less than in Poland, and almost 6 times less than in Hungary. At the same time, Ukraine has a much higher agricultural land load per worker. All the above shows the much worse competitive position of Ukrainian farmers in the supply of basic energy resources. To a certain extent, this is due to the dominance of small family farms in Poland compared to the dominance of agricultural holdings in Ukraine. Thus, in Poland large farms (more than 100 hectares of land) owned 22\% of all lands, while in some other countries of Eastern Europe this share was dominant: in Bulgaria - 82\%, in Estonia - 73\% (Markitanenko, 2018).

In order to be able to compare resource availability indicators by region and estimate their dynamics, we calculated security indices by taking the industry average values for 1 , and the corresponding indices were calculated by formula 1 for the regions.

$$
\text { Isec }_{\mathrm{ij}}=\Pi \operatorname{reg}_{\mathrm{ij}} / \Pi \mathrm{\Pi av}_{\mathrm{i}}
$$

where $\mathrm{Isec}_{\mathrm{ij}}$ - security index of the $\mathrm{j}$-th region $\mathrm{i}$-th resource

$\Pi_{j}$ reg $_{i}-$ security indicator for the i-th resource of the j-th region

$\Pi_{a v_{i}}$ - security indicator of the i-th resource on the average in Ukraine

Then it is determined the geometric mean of integral index of resource availability (formula 2).

$$
\text { Isec }_{\mathrm{j}}=\sqrt[3]{I_{e j}^{*} I_{m j} * I_{L j}}
$$

where Isec $c_{j}$ - integral index of resource security of the $\mathrm{j}$-th region

$\mathrm{I}_{\mathrm{ej}}$ - energy supply index of the $\mathrm{j}$-th region

$\mathrm{I}_{\mathrm{Tj}}$ - index of supply of tractors of the $j$-th region

$\mathrm{I}_{\mathrm{Lj}}$ - j-th region labor supply index
The results of the calculations are shown in Figure1.

As evidenced by Fig., there are almost no relative changes in the resource indices in the dynamics, so it can be concluded that the competitive advantage in the provision of material and labor resources is relatively stable, since the low labor mobility and high immobility of the land resources make it impossible to overcome the backlog from competitors in the short term.

Resource efficiency in agriculture is characterized primarily by labor productivity indicators (gross output per 1 average annual worker) and land productivity (gross output per 1 hectare of agricultural land). As a result of the analysis, labor and land productivity indices were calculated as well as an integral index of resource efficiency (formulas 3-5)

$$
\mathrm{I}_{\mathrm{LPj}}=\mathrm{LP}_{\mathrm{j}} \mathrm{reg} / \mathrm{LPav} \text {, }
$$

where $\mathrm{I}_{\mathrm{LPj}}$-labor productivity index of the $\mathrm{j}$-th region $\mathrm{LP}_{\mathrm{j}}$ reg -labor productivity indicator of the $\mathrm{j}$-th region LPav - the indicator of labor productivity on the average across Ukraine

$$
\mathrm{I} l \mathrm{p}_{\mathrm{j}}=\ell \mathrm{P}_{\mathrm{j}} \mathrm{reg} / \ell \mathrm{Pav} \text {, }
$$

where $I l p_{j}$ - index of land productivity of the $j$-th region

$l \mathrm{P}_{\mathrm{j}}$ reg - the indicator of land productivity in the $\mathrm{j}$-th region

Pav - the indicator of land productivity on average in Ukraine

$$
\operatorname{Ier}_{\mathrm{j}}=\sqrt[2]{I_{L P j} * I_{l P j}}
$$

where Ier $_{j}$ - integral index of resource efficiency of $j$-th region

The dynamics of the integral efficiency index is shown in Figure 2.

Despite some fluctuations, there is a general tendency to exceed the Resource Efficiency Index in Sumy Oblast 
Vol. 5, No. 5, 2019

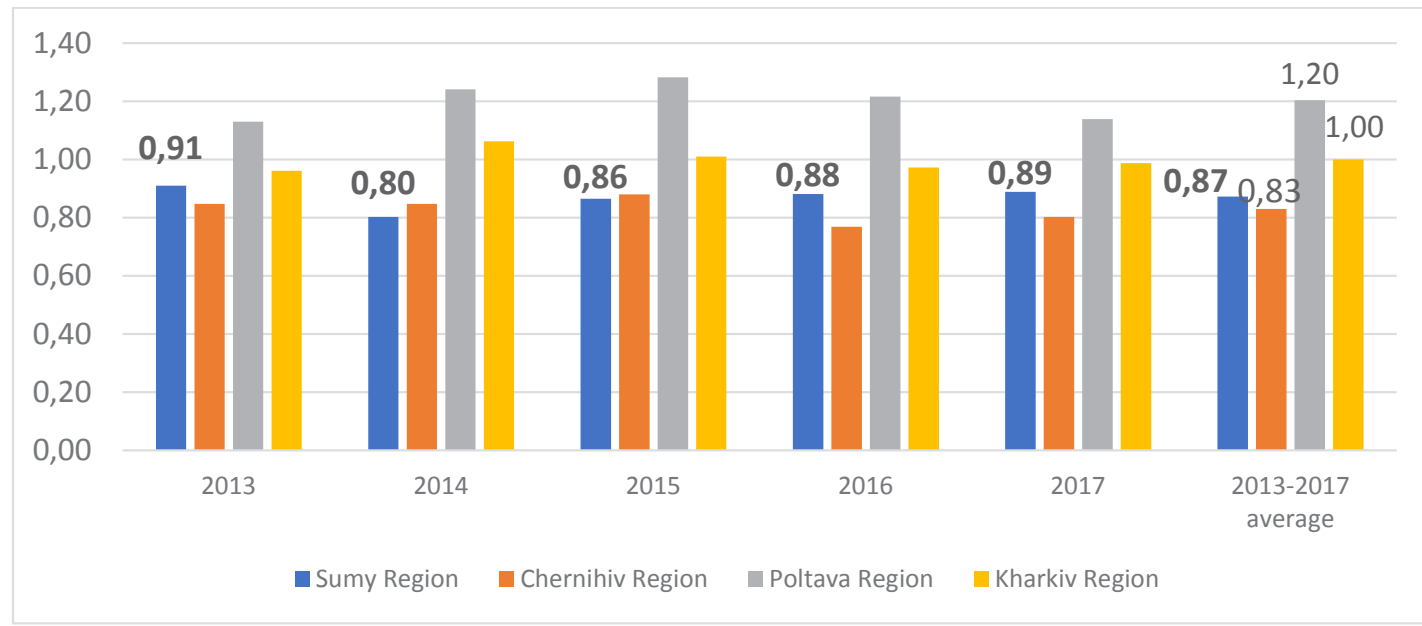

Figure 1. Dynamics of the integral index of resource security for 2013-2017

Source: calculated by the authors

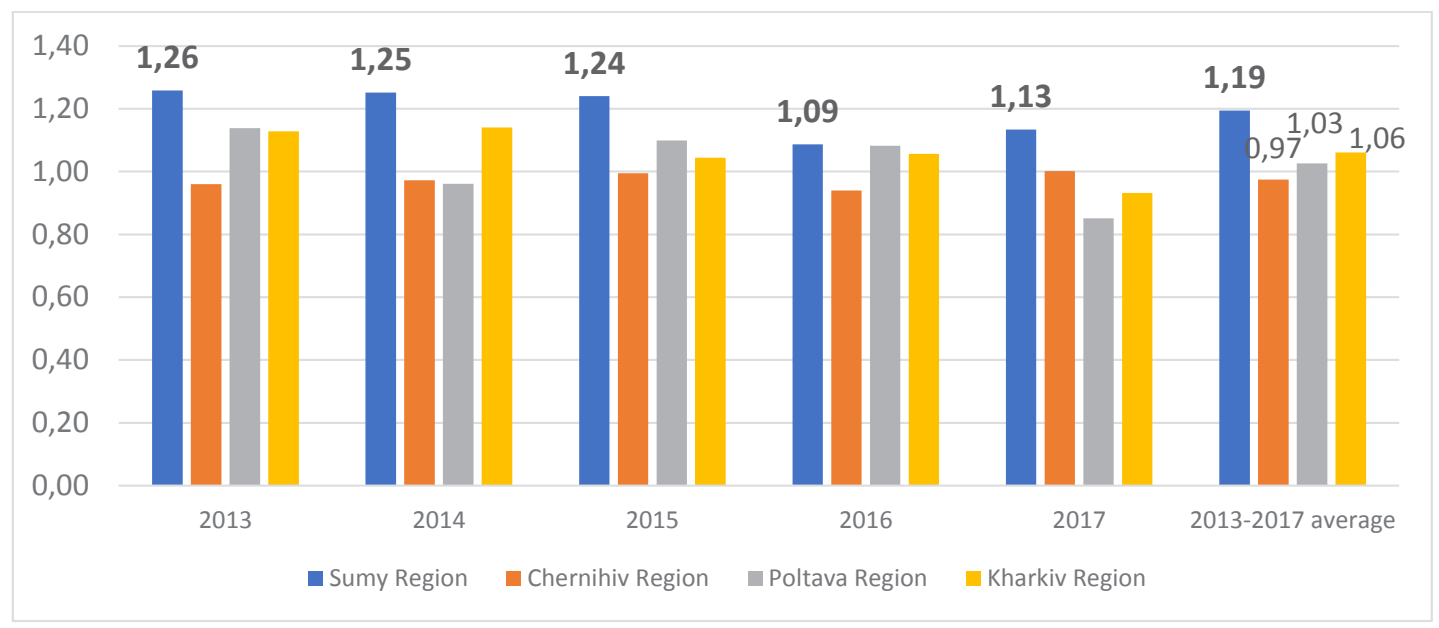

Figure 2. Dynamics of the integral index of resource efficiency

Source: calculated by the authors

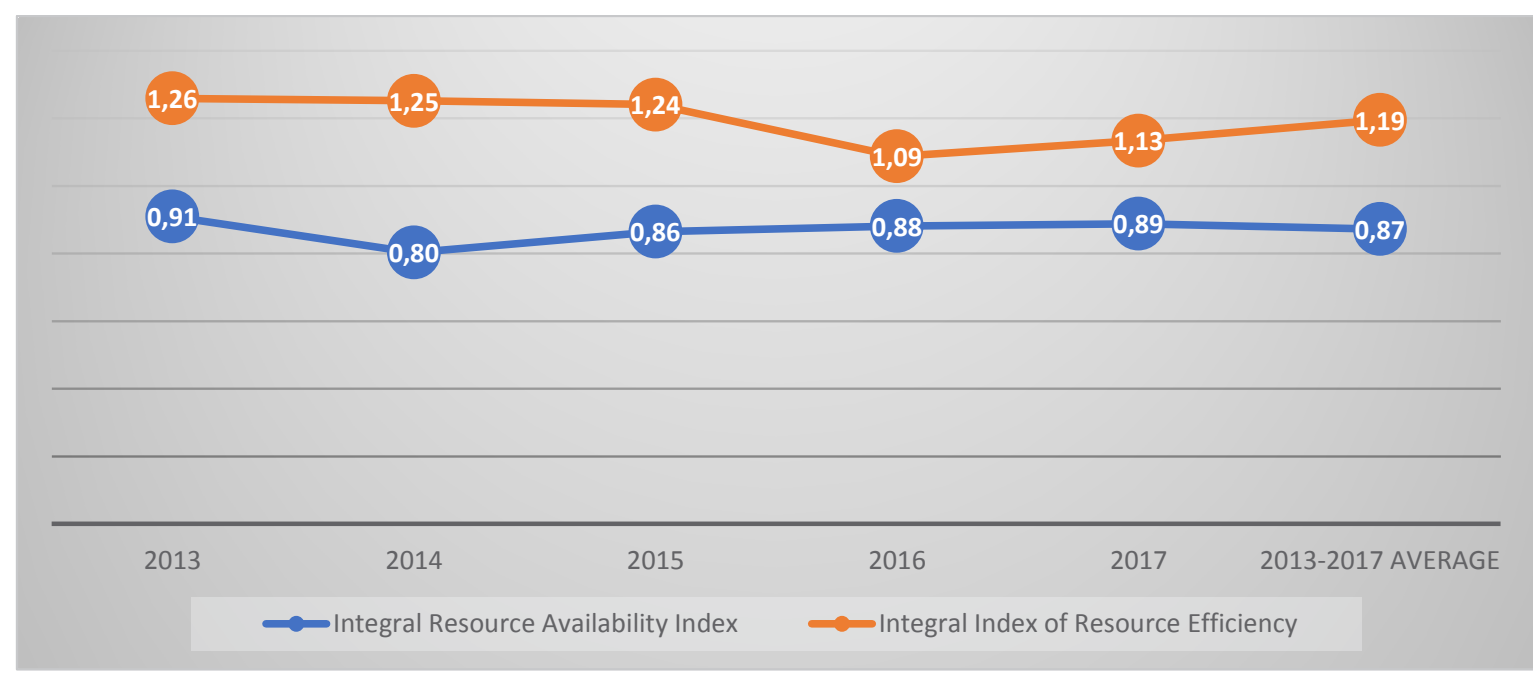

Figure 3. Dynamics of integral indices of security and efficiency of use

of agricultural resources enterprises of Sumy Region for the period 2013-2017

Source: calculated by the authors 
Table 2

Dynamics of the average monthly wage in agriculture for the period 2013-2017, UAH

\begin{tabular}{|l|l|l|l|l|l|c|}
\hline \multicolumn{1}{|c|}{ Regions } & 2013 & 2014 & 2015 & 2016 & 2017 & 2017 in \% to 2013 \\
\hline Ukraine & 2270 & 2476 & 3140 & 3916 & 5761 & 254 \\
\hline Sumy Region & 2143 & 2391 & 3134 & 3724 & 5936 & 277 \\
\hline Chernihiv Region & 2157 & 2521 & 3522 & 4600 & 6436 & 298 \\
\hline Poltava Region & 2404 & 2631 & 3390 & 4452 & 6136 & 255 \\
\hline Kharkiv Region & 2396 & 2601 & 3089 & 3654 & 5259 & 219 \\
\hline
\end{tabular}

Source: the authors calculated on the basis of data (Derzhavna sluzhba statystyky, 2019)

compared to both neighboring regions and industry average values.

Comparing the dynamics of the integral indices of security and efficiency of resource use (Figure 3), we conclude that agricultural enterprises of Sumy region use resources much more effectively than in Ukraine as a whole.

And over the years, the trend is practically unchanged, which indicates the existence of sustainable competitive advantages. It is logical to assume that the basis for this is the available human potential since, in terms of natural resources, none neighboring region concedes to Sumy but also has certain advantages. At the same time, analyzing the level of remuneration in the agricultural sector enterprises, we see a rather contradictory trend (Table 2).

Wage growth rates in Sumy region are inferior to Chernihiv region only, but the wage level is lower than in Chernihiv and Poltava regions. In this case, an optimal solution to the problem of labor resources' motivation in wages at agricultural enterprises can be considered the adjustment of the employee's salary tax scheme that will help the owners of the business to raise employees' wages (Klietsova, 2018).

If we determine the wage index using the method described above and compare it with the integral index of resource efficiency (Figure 4), we can see that in agriculture of Sumy and Kharkiv Regions it is underpaid, and in Chernihiv and Poltava Regions it is overpaid.
Given the rapid changes in the business environment, any competitive advantage can quickly turn from sustainable to unstable. Therefore, the ability of business entities to respond quickly and adapt to changes in the business environment is one of the most important characteristics that will provide a sustainable position. The more effective the adaptation mechanism of the enterprise is, the more stable its position in the market can be. The basis for ensuring an effective adaptation mechanism is a clearly defined set of resources, but not every resource can carry adaptability characteristics. In the conditions of rapid technological changes, the most important resource is still human resources that can produce certain knowledge and innovative solutions.

\section{Conclusions}

1. Every concept has its advantages and disadvantages, but the combination of the two approaches and their practical usage by agricultural enterprises will provide the high efficiency of the competitive advantage mechanism.

2. An assessment of the competitive advantages of the agrarian sector in the region has shown that to provide a sustainable position, it is first and foremost necessary to pay attention to the cost reduction and innovation.

3. Human resources, which can produce certain knowledge and innovative solutions, are the main

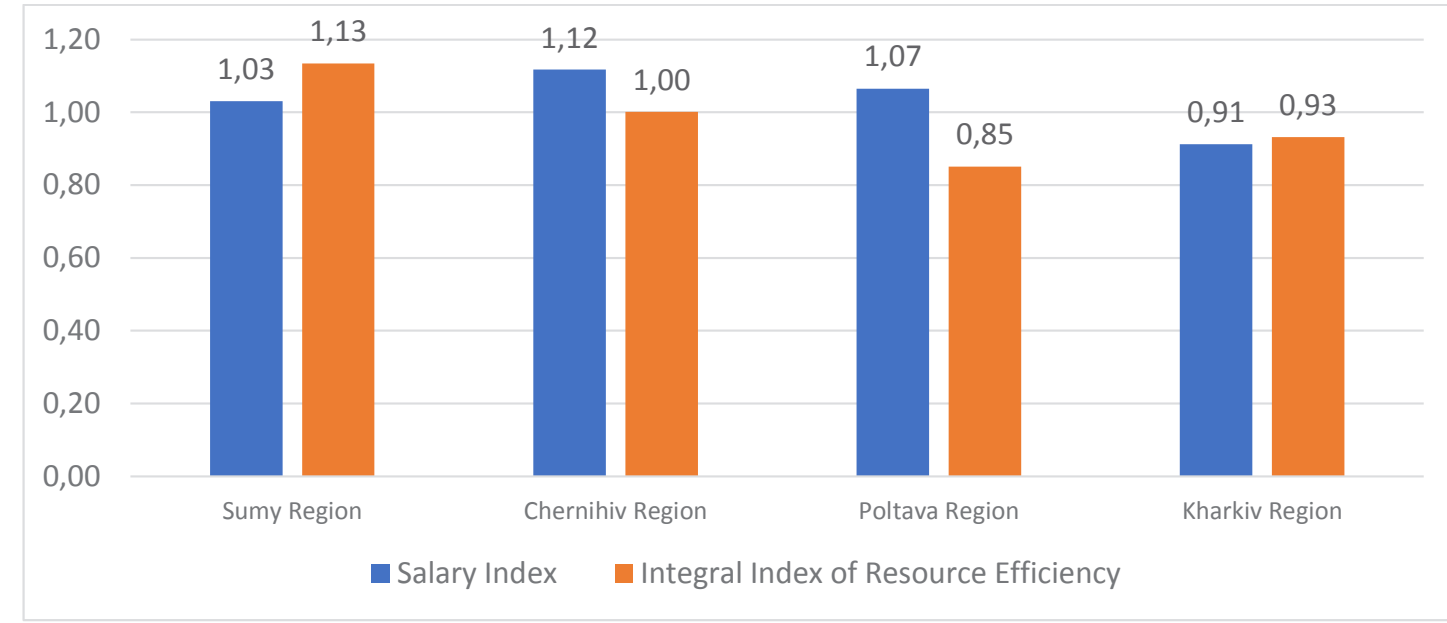

Figure 4. Comparison of the Integrated Resource Efficiency Index and the Salary Index by Regions, 2017

Source: calculated by the authors 
resource in agriculture, capable of providing sustainable competitive advantages in the conditions of rapid technological changes.

4. The proposed author's method of calculation of integral indicators of resource availability and efficiency of their usage allows evaluating the availability of competitive advantages objectively and can be used both for the development of competitive strategies by agricultural enterprises as well as in the preparation and decision making at the level of central and regional authorities.

\section{References:}

Pylypenko, V. V., \& Pylypenko, N. M. (2016). Naukovo-praktychni aspekty ocinky konkurentospromozhnosti siljsjkoghospodarsjkykh pidpryjemstv [Scientific and practical aspects of the assessment of the competitiveness of agricultural enterprises]. Bulletin of Sumy NAU, 1(67), 73-78. (in Ukrainian)

Ghadzalo, Ja. M., \& Zhuk, V. M. (2015). Naukovi osnovy rozvytku aghrarnogho pidpryjemnyctva ta siljsjkykh terytorij za selozberighajuchoju modellju (naukova dopovidj) [Scientific bases of development of agrarian entrepreneurship and rural territories according to the village conservation model (scientific report)]. Kyiv: IAE National Science Center. (in Ukrainian)

Barney, Jay (1991). Firm Resources and Sustained Competitive Advantage. Journal of Management, 17(1), 99-120. URL: http://www.business.illinois.edu/josephm/BA545_Fall\%202011/S10/Barney\%20(1991).pdf (accessed 20 January 2019).

Vinayan, Gowrie, Jayashree, Sreenivasan \& Marthandan, Govindan (2012). Critical Success Factors of Sustainable Competitive Advantage: A Study in Malaysian Manufacturing Industries. International Journal of Business and Management, 7(22). doi: 10.5539/ijbm.v7n22p29 (accessed 17 June 2019).

Barney, J. B., D. J. Ketchen Jr, \& M. Wright. (2011). The Future of Resource-Based Theory. Journal of Management, 37(5), 1299-1315. doi: 10.1177/0149206310391805 (accessed 3 March 2019).

Porter, M. E. (1985). Competitive Advantage. New York: The Free Press.

Peteraf, Margaret A. (1993). The Cornerstones of Competitive Advantage: A Resource-Based View. Strategic Management Journal, 14(3), 179-191. URL: http://links.jstor.org/sici?sici=0143-2095\%28199303\%2914\%3A3\% 3C179\%3ATCOCAA\%3E2.0.CO\%3B2-A (accessed 11 May 2019).

Wernerfelt, B., (1984). A resource-based view of the firm. Strategic Management Journal, 5(2), $171-180$. URL: http://links.jstor.org/sici?sici=0143-2095\%28198404\%2F06\%295\%3A2\%3C171\%3AARVOTF\%3E2.0. CO\%3B2-L (accessed 27 May 2019).

Prahalad, C. K., \& Hamel, G. H. (1990). The core competencies of the Corporation, Harvard Business Review, 3. URL: https://edisciplinas.usp.br/pluginfile.php/4391952/mod_resource/content/1/Prahalad\%20Hamel.pdf (accessed 8 June 2019).

Grant, R. (1991). The Resource-based Theory of Competitive Advantage: Implications for Strategy Formulation. California Management Review, (Spring): 114-135. doi: 10.1016/B978-0-7506-7088-3.50004-8 (accessed 8 April 2019).

Wang, H. (2014). Teories for competitive advantage. In H. Hasan (Eds.), Being Practical with Teory: A Window into Business Research, pp. 33-43. Wollongong, Australia: THEORI. URL: https://ro.uow.edu.au/cgi/viewcontent. cgi? article $=1410 \&$ context $=$ buspapers $($ accessed 14 May 2019).

Urlich D., \& Lake D. (1991). Organizational capability: Greating competitive advantage. Academy of management Executive, 7(1), 77-92. URL: https://journals.aom.org/doi/10.5465/AME.1991.4274728 (accessed 24 May 2019). Grant, R. (1996). Toward a Knowledge-based Theory of the Firm. Strategic Management Journal, 17, $109-122$. URL: https://pdfs.semanticscholar.org/e8f7/94a511c356a254cc4998f2dc6e4e2c88fcbb.pdf (accessed 11 April 2019). Mugera, Amin W., (2012). Sustained Competitive Advantage in Agribusiness: Applying the ResourceBased Theory to Human Resources. International Food and Agribusiness Management Review, 15(4), $27-48$. URL: http://ageconsearch.umn.edu/record/138318/files/20120017_Formatted.pdf (accessed 29 May 2019).

Hart, S. (1995). A Natural Resource-based View of the Firm. The Academy of Management Review, 20(4), 986-1014. URL: http://faculty.wwu.edu/dunnc3/rprnts.naturalresourceviewofthefirm.pdf (accessed 14 May 2019).

Yudanov, A. Yu. (2000). Strategicheskie konkurentnye preimushchestva firmy i puti ikh realizatsii na rynke [Strategic competitive advantages of the company and ways to market them]. Personal, 6, 25-31. URL: https://www.cfin.ru/management/strategy/yudanov.shtml

Derzhavna sluzhba statystyky (2019). URL: http://ukrstat.gov.ua/ (accessed 24 May 2019).

Markitanenko, S. (2018). Efektyvni fermery chy neefektyvni ahrokholdynhy? Effective farmers or inefficient agricultural holdings? URL: https://latifundist.com/193-efektivn-fermeri-chi-neefektivn-agroholdingi (accessed 02 November 2019).

Klietsova, N. (2018). Improvement of the Ukrainian Labor Legislation Concerning the Hired Workers' Employment Protection in the Context of European Integration. Nauchni trudove (University of National and World Economy, Sofia, Bulgaria), 2, 251-264. 